\title{
UPAYA PENCEGAHAN COVID-19 MELALUI PEMBAGIAN MASKER SERTA MINUMAN BERGIZI KEPADA MASYARAKAT BANJARBARU DAN MARTAPURA
}

\author{
Lena Rosida $^{1}$, Triawanti $^{2}$, Asnawati ${ }^{1}$, Didik Dwi Sanyoto' ${ }^{1}$, Roselina Panghiyangani' ${ }^{1}$, \\ Lisda Hayatie H $^{3}$ \\ ${ }^{1}$ Departemen Biomedik Fakultas Kedokteran Universitas Lambung Mangkurat \\ ${ }^{2}$ Departemen Biokimia dan Biomolekuler Fakultas Kedokteran Universitas Lambung Mangkurat \\ ${ }^{3}$ Departemen Mikrobiologi Parasitologi Fakultas Kedokteran Universitas Lambung Mangkurat
}

Email: ${ }^{1}$ lrosida@ulm.ac.id., ${ }^{2}$ triawanti@ulm.ac.id., ${ }^{3}$ asnawati@ulm.ac.id., ${ }^{4}$ didikdwisanyoto@ulm.ac.id.,

5roselina.darma@gmail.com, ${ }^{6}$ lhayatie@ulm.ac.id.

\begin{abstract}
COVID-19 cases in Indonesia are increasing as of April 10, reaching 3512 people who have been declared infected with COVID-19, with a death toll of 306 people (8.71\%). One of the prevention efforts is to use mask and hand sanitizer and increase immunity status through consumption of nutritious food and drinks. Prevention efforts will work well if we invite the public to participate actively, one of which is the Khosya Berbagi community in Banjarbaru.This activity aims to distribute masks, hand sanitizers and nutritious drinks to the people of Banjarbaru and Martapura, especially those who are vulnerable and have a high risk of being infected with COVID-19. The methods used include identifying people who are prone to infection and have a high risk of infection, making mask, COVID-19 prevention stickers, packaging mask and nutritious drinks, namely honey and milk, followed by distributing gifts to the community. This activity has succeeded in distributing 500 packages consisting of cloth mask, nutritious drinks and hand sanitizer to small traders, pedicab drivers, motorcycle taxi drivers, and road cleaners in Banjarbaru and Martapura. This parcel is also equipped with stickers on efforts to prevent COVID-19. It is hoped that this activity can help people protect themselves from COVID-19.
\end{abstract}

Key words: COVID-19, prevention, cloth mask, hand sanitizer, nutritious drinks

\section{PENDAHULUAN}

Pandemi Corona virus disease (COVID-19) merupakan masalah kesehatan yang sedang dihadapi oleh hampir 200 lebih Negara di seluruh dunia, tidak terkecuali Indonesia. Penyakit ini selain memiliki tingkat menularkan yang tinggi (virulensi) juga menyebabkan kematian. Di Indonesia, tingkat kematian akibat infeksi COVID-19 mencapi 8,7\%. Berbagai upaya telah dilakukan pemerintah dalam mengatasi masalah ini, mulai dari pembentukan gugus tugas penanganan bencana hingga pembuatan regulasi, antara lain dengan dikeluarkanya pedoman pencegahan dan pengendalian.

Bagi Indonesia untuk menurunkan epidemic peak agar tidak membuat negara kewalahan dalam menangani wabah ini, antara lain dengan cara Karantina wilayah/lockdown dalam skala terbatas (PSBB), namun memerlukan biaya yang sangat besar, memperketat himbauan untuk diam di rumah, meningkatkan pelayanan kesehatan, serta meningkatkan ketersediaan alat pelindung diri (APD) dalam hal ini masker serta upaya 
peningkatan kesadaran untuk cuci tangan dengan sabun (Setiatio dan Azwar, 2020).

Upaya penggunaan masker terus digaungkan oleh pemerintah, termasuk meningkatkan pengetahuan masyarakat akan pentingnya menggunakan masker. Penelitian Sari dan Atiqoh (2020) mendapatkan hubungan antara pengetahuan masyarakat dengan kepatuhan menggunakan masker. Variabel pengetahuan memberikan pengaruh yang signifikan terhadap perilaku kepatuhan.

Berbagai jenis masker memiliki tingkat proteksi yang berbeda-beda. Masker bedah jauh lebih efektif karena mampu memproteksi partikel ukuran virus. Penelitian Bartoszko et al. yang membandingkan masker bedah dengan masker N95 dalam khasiatnya untuk mencegah coronavirus pada pekerja kesehatan, menemukan bahwa masker bedah dan masker N95 memiliki perlindungan yang sama terhadap infeksi pernapasan virus termasuk coronavirus pada petugas layanan kesehatan (Hirschmann et al., 2020). Namun demikian, untuk masyarakat umum dianjurkan untuk menggunakan masker kain.

Penggunaan masker, ditambah dengan pemakaian kaca penutup wajah serta peningkatan personal hiegine akan mampu meningkatkan perlindungan yang optimum terhadap COVID-19. Adaptasi kebiasaan berupa kebersihan tangan sangat penting, salah satu saran dari WHO adalah dengan mencuci atau sering membersihkan tangan dengan sabun atau hand sanitizer beralkohol dengan konsentrasi > 60\% (Mahmood et al., 2020).

Upaya pencegahan COVID-19 lainnya yaitu dengan meningkatkan imunitas tubuh. Sampai saat ini vaksinasi belum ada, upaya meningkatkan status imunitas dapat dilakukan dengan mengonsumsi makanan sehat dan bergizi. Telah banyak penelitian yang menyatakan bahwa ada hubungan imunitas seseorang dengan nutrisinya. Konsumsi madu sangat baik untuk meningkatkan sistem imun. Beberapa manfaat madu yaitu antioksidan, antibakteri, antidiabetik, anti-inflamasi, melindungi saluran cerna, kardiovaskular dan sistem saraf (Samarghandean et al, 2017). Selain madu, konsumsi susu juga akan meningkatkan sistem imun. Susu banyak mengandung protein yang diperlukan oleh sel-sel imun untuk dapat bekerja aktif melawan virus atau mikroba yang masuk dalam tubuh. Susu direkomendasikan untuk dikonsumsi oleh mereka yang berada pada masa karantina (Muscogiuri et al, 2020).

Berdasarkan penjelasan sebelumnya, maka pada saat ini yang diperlukan untuk menurunkan angka kejadian positif COVID-19 yaitu dengan mencegah agar tidak terinfeksi. Untuk itu masyarakat perlu diberi pemahaman yang baik melalui media misalnya brosur yang berisi tentang pencegahan COVID-19, pemberian masker dan hand sanitizer secara gratis serta asupan gizi yang menunjang sistem imun. Masyarakat yang banyak beraktivitas di tempat umum seperti pedagang, tukang ojek, tukang becak sangat rawan terinfeksi dan bahkan menularkan pada orang lain jika dia terinfeksi namun tidak bergejala. Dengan demikian maka tujuan kegiatan pengabdian masyarakat ini adalah untuk mencegah penularan COVID-19 melalui pemberian edukasi secara tertulis dengan media brosur, pemberian masker, hand sanitizer, madu dan susu kepada masyarakat yang rawan terinfeksi di daerah Banjarbaru dan Martapura. Kegiatan dilakukan secara langsung dengan melibatkan komunitas masyarakat Khosya Berbagi dan relawan Covid Fakultas Kedokteran ULM.

\section{METODE}

Kegiatan pengabdian masyarakat ini melibatkan relawan Covid Fakultas Kedokteran ULM dan kelompok masyarakat yaitu Komunitas Khosya Berbagi sebagai mitra pelaksana. Tujuan pelibatan mitra yaitu untuk meningkatkan kepedulian kelompok masyarakat terhadap permasalahan kesehatan terutama COVID-19 dan upaya pencegahannya. Komunitas Khosya Berbagi merupakan komunitas yang menyelenggarakan kegiatan berbagi kebaikan dalam hal apa saja sebagai bentuk kepedulian terhadap masyarakat. Komunitas ini diprakarsai oleh alumni Pondok Pesantren Darul Hijrah Putri Martapura.

Pada kegiatan ini dilaksanakan langkahlangkah sistematis berupa 1) identifikasi masyarakat yang rawan dan memiliki risiko tinggi terinfeksi COVID-19; 2) pembuatan masker dan brosur pencegahan COVID-19 dalam bentuk stiker; 3) pengemasan bingkisan yang berisi masker, handsinitizer, madu dan susu; 4) pembagian bingkisan langsung ke masyarakat yang rawan dan memiliki risiko tinggi terinfeksi COVID-19.

Kesehatan 
Sasaran kegiatan ini adalah masyarakat yang rawan dan memiliki risiko tinggi terinfeksi COVID-19 yang dilihat berdasarkan aktifitasnya di tempat umum antara lain pedagang keliling, tukang becak, tukang ojek,dan petugas kebersihan jalan raya. Hal ini menjadi pertimbangan karena mereka tidak dapat melakukan kerja dari rumah (work from home) dan harus bekerja untuk mendapat penghasilan setiap hari. Dengan demikian maka kelompok masyarakat ini sangat rentan untuk terinfeksi COVID-19 dan bahkan potensial menularkan pada orang lain apabila mereka terinfeksi namun tanpa gejala.

Bahan dan alat yang digunakan berupa kain untuk bahan masker, larutan hand sanitizer, botol kecil sebagai wadah hand santizer, madu sachet, susu kaleng, kantong plastik untuk mengemas, brosur berupa stiker, dan alat-alat menjahit.

Waktu pelaksanaan adalah tanggal 15 - 20 April 2020.Tempat pelaksanaan di kampus FK ULM dan pasar serta tempat-tempat umum di wilayah Banjarbaru dan Martapura.

\section{HASIL DAN PEMBAHASAN}

Cepatnya penyebaran virus penyebab COVID-19, menyebabkan pemerintah dengan segera menerapkanprotokol kesehatan untuk mencegah rantai penularan virus Covid 19. Salah satunya adalah mewajibkanseluruh masyarakat untuk memakai masker saat beraktivitas di luar rumah (Lestari dkk., 2020). Dalam rangka mendukung program tersebut, maka tim Dosen PSPD FK ULM mengadakan kegiatan Pengabdian Kepada Masyarakat berupa pembagian masker dan minuman bergizi bagi masyarakat Banjarbaru dan Martapura, Kalimantan Selatan pada tanggal 15 20 April 2020. Kegiatan ini didanai dari dana PNBP Fakultas Kedokteran Universitas Lambung Mangkurat.Tujuan kegiatan ini adalah untuk mendukung upaya pencegahan COVID-19 melalui penggunaan masker dan peningkatan pertahanan tubuh masyarakat.

Kegiatan diawali dengan mengirimkan surat pemberitahuan kegiatan kepada Satgas COVID-19 Martapura dan Banjarbaru, Camat Martapura, dan dinas Kesehatan Kabupaten Banjar. Selanjutnya tim berkoordinasi dengan relawan COVID-19 Fakultas Kedokteran dan anggota Kosya Berbagi yang nantinya akan membantu pendistribusian masker dan minuman bergizi kepada masyarakat.

Setelah persiapan lapangan dan tenaga distribusi selesai, tim pengabdian kemudian melakukan langkah-langkah berikut:

1. Persiapan produksi masker, mulai dari pemilihan dan pembelian bahan kemudian dijahit oleh Dosen dan MahasiswaPSPD FK ULM. Selain memproduksi sendiri, sebagian masker juga dibeli dari tukang jahit yang berubah haluan menjahit masker di masa pandemi ini.

2. Persiapan kemasan yang akan dibagikan, mulai dari diskusi desain kemasan hingga isibrosur yang akan diselipkan ke dalam kemasan tersebut.

3. Proses packing atau mengemasan masker dan minuman kedalam kemasan yang sudah disiapkan serta menyelipkan brosur protokol kesehatan untuk pencegahan penyebaran virus COVID-19. Selain masker dan minuman kesehatan, tim pengabdian juga memberikan handsanitizer yang didapatkan dari laboratorium FMIPA Universitas Lambung Mangkurat.

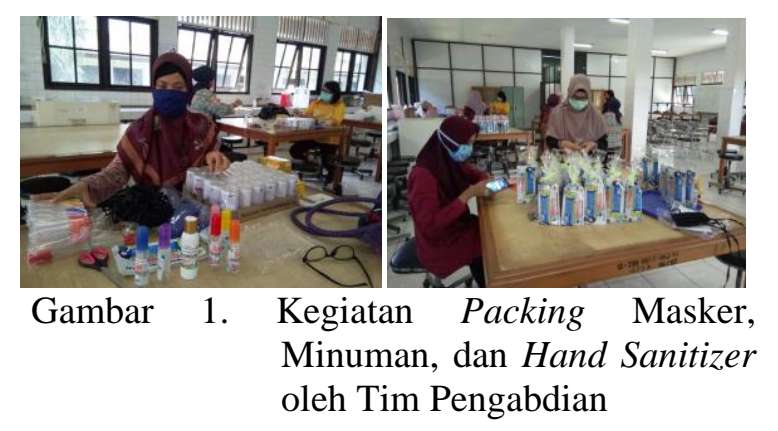

4. Pendistribusian paket masker, minuman kesehatan, dan handsanitizer kepada sasaran. Kegiatan ini dilakukan oleh tim pengabdian bersama relawan Codid-19 Fakultas Kedokteran ULM dan komunitas Khosya Berbagi secara langsung kepada sasaran yaitu masyarakat yang banyak beraktivitas di tempat umum seperti pedagang, tukang ojek, tukang becak, dan petugas kebersihan jalan raya. Karena kegiatan ini langsung terjun ke masyarakat, maka semua tim diberikan arahan agar disiplin melakukan protocol kesehatan dengan memakai masker, jaga jarak dan sering cuci tangan pakai sabun atau handsanitizer.

Kesehatan 281 


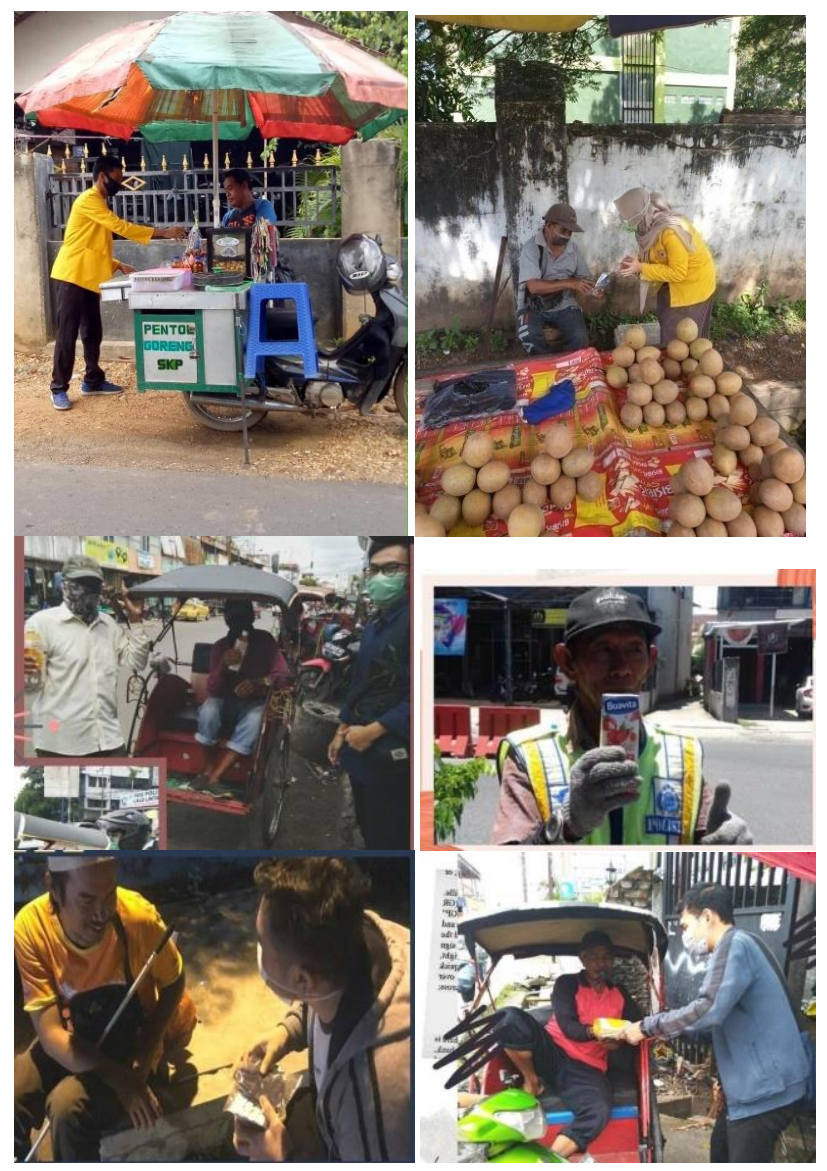

Gambar 2. Pendistribusian Bingkisan

Informasi yang ada saat ini mengindikasikan bahwa dua cara utama transmisi virus COVID-19 adalah percikan (droplet) saluran pernapasan dan kontak.Sesuai dengan anjuran Kementerian Kesehatan RI, semua orang disarankan untuk memakai masker kain ketika harus bepergian ke luar rumah, untuk mengantisipasi penularan penularan virus COVID-19. Virus ini terdapat pada percikan air liur orang yang sakit ketika ia bersin, batuk, atau bahkan saat berbicara. Penularan dapat terjadi ketika percikan air liur terhirup orang lain yang ada di sekitar.Masker kain dapat menghalau sebagian percikan air liur yang keluar saat berbicara, menghela napas, ataupun batuk dan bersin (WHO,2020).
Masker kain dapat digunakan untuk mencegah penularan sekaligus mengantisipasi kelangkaan masker yang terjadi di pasaran, seperti apotek dan toko-toko kesehatan. WHO mengeluarkan pedoman baru tentang komposisi masker kain non-medis untuk masyarakat umum. WHO menyarankan masker harus terdiri dari setidaknya tiga lapisan bahan yang berbeda. Lapisan paling dalam harus terbuat dari bahan penyerap air seperti kapas dan bahan yang lembut lantaran bersentuhan langsung dengan kulit. Lapisan tengah, yang berfungsi sebagai filter terbuat dari bahan seperti polipropilena nonanyaman. Lapisan luar harus terbuat dari bahan yang tahan air seperti polyester (WHO, 2020).

Walaupun penggunaan masker kain non medis merupakan alternatif terakhir jika pilihan masker medis dan masker N95 tidak tersedia. Penggunaan masker kain non medis dapat dipergunakan untuk masyarakat umum dalam keadaan sehat. Masker jenis ini bisa digunakan ketika berada di tempat umum dan fasilitas lainnya dengan tetap menjaga jarak aman physical distancingyakni 1-2 meter (Dewi dan Utami, 2020).

Masker kain perlu dicuci dan dapat dipakai berkali-kali. Oleh karena itu pencucian dan penyimpanan harus tepat. Bahan yang digunakan untuk masker kain berupa bahan kain katun, scarf, dan sebagainya. Masker kain dapat dipakai maksimal hanya 4 jam dan harus ganti dengan masker baru dan bersih. Apabila masker yang dipakai basah atau lembab harus segeradiganti. Masyarakat disarankan membawa beberapa masker untuk beraktivitas, cara menggunakan masker harus tepat seperti menutup hidung dan mulut. Cara melepas masker cukup dengan menarik bagian tali dan langsung disimpak ke kentong kertas atau plastik tertutup guna mencegah penyebaran virus kebarang di sekitarnya (Kemkes, 2020).

Jika masker kain non medis digunakan dengan benar, masker ini tetap dapat mengurangi penyebaran virus COVID-19di masyarakat, terutama dari orang yang terinfeksi virus namun tidak memiliki gejala apa pun. 
Dalam menggunakan masker untuk mencegah penularan virusCOVID-19, apapun jenis maskernya, harus dipahami cara pemakaian yang tepat untuk memastikan masker tersebut efektif dan untuk menghindari peningkatan penularan. Selain itu, menjalankan protokol kesehatan seperti cuci tangan dan menjaga jarak aman juga sama pentingnya dengan memakai masker. Pastikan selalu mencuci tangan setiap usai melakukan atau menyentuh sesuatu, terutama di tempat umum (WHO, 2020;Kemkes RI,2020).

Upaya lainnya yang dapat dilakukan masyarakat untuk mencegah penularan adalah meningkatkan imunitas tubuh, di antaranya dengan mengkonsumsi madu dan susu. Keduanya banyak mengandung vitamin dan protein yang baik bagi tubuh.Seseorang dengan sistem pertahanan tubuh yang prima, memiliki respon imun yang baik di mana tubuhnya dapat segera memproduksi antibodi ketika antigen terdeteksi.

Madu mengandung mikronutrien yang tinggi yakni kalsium $(\mathrm{Ca})$, tembaga $(\mathrm{Cu})$, zat besi $(\mathrm{Fe})$, magnesium $(\mathrm{Mg})$, fosfor $(\mathrm{P})$, potassium $(\mathrm{K})$, sodium $(\mathrm{Na})$, yodium (I) dan Zinc ( $\mathrm{Zn})$. Zinc memegang peranan penting untuk kesehatan tubuh. Jika kekurangan zinc bisa menyebabkan kesehatan menurun, mudah terkena infeksi, dan sering terjadi gangguan kulit (Yuliarti, 2015).

Madu juga mengandung vitamin $\mathrm{A}, \mathrm{C}$, K, B2 (riboflavin), B3 (niacin), B5 (pantotenat), B6 (piridoksin), dan B9 (folat) (Yuliarti, 2015). Madu juga mengandung enzim glucose oxidase yang berperan dalam penghambatan pertumbuhan bakteri, jamur dan virus. Di samping itu, prebiotic fructooligosacharide yang terdapat pada madu menjadi makanan bakteri baik di saluran cerna. Ini merupakan hal baik karena $70 \%$ sistem imun tubuh dipengaruhi kesehatan saluran pencernaan (Uly, 2020).

Mengonsumsi madu setiap hari sangat baikuntuk menjaga kesehatan. Madu aman untuk dikonsumsi maksimal 3 sendok makan setiap hari dalam jangka waktu yang lama. Untuk menjaga kesehatan 2 sendok makan madu dan $1 / 2$ sendok teh bubuk kayu manis dilarutkan dalam $200 \mathrm{cc}$ air teh hangat, minum 1-2 gelas sehari secara rutin 2-3 kali seminggu (Yuliarti, 2015).

Sementara susu menjadi sumber protein hewani yakni mengandung asam amino essensial. Protein ini baik untuk meningkatkan kekebalan tubuh. Kandungan vitamin E dan zat besi dalam susu murni dapat meningkatkan sistem kekebalan tubuh. Selain itu, susu juga mengandung vitamin $\mathrm{A}$, asam linolenat dan omega 3 yang mampu meningkat daya tahan tubuh. Oleh sebab itu disarankan untuk mengonsumsi susu sebanyak 200-250 mg per hari bagi orang dewasa (Uly, 2020).

\section{KESIMPULAN}

Pengabdian kepada masyarakat yang dilakukan oleh dosen-dosen PSPD FK ULM berupa pembagian masker kain dan minuman bergizi kepada masyarakat yang memiliki risiko tinggi di Banjarbaru dan Martapura ini diharapkan dapat memotivasi masyarakat selalu menggunakan masker jika beraktivitas di tempat-tempat umum agar terhindar dari penularan COVID-19, serta meningkatkan imunitas tubuh dengan mengkonsumsi makanan bergizi.

\section{UCAPAN TERIMA KASIH}

Ucapan terima kasih kami sampaikan atas partisipasi berbagai pihak yang membantu pelaksanaan kegiatan ini, yaitu:

1. Fakultas Kedokteran ULM

2. Relawan COVID-19 Fakultas Kedokteran ULM

3. Komunitas Khosya Berbagi

\section{REFERENSI}

Dewi NAP dan Utami S, 2020. Perancangan masker kain sebagai alat pelindung diri dalam sistem sustainable fashion, Jurnal Da Moda, 1 (2):

Kesehatan

283 
75-87 (online). $\quad$ https://jurnal.stdbali.ac.id/index.php/damoda/article/view/81/ $\underline{59 .}$.

Hirschmann MT, Hart A, Henckel J, Adoghi P, Seil

$\mathrm{R}$ dan Mouton C, 2020. COVID-19 coronavirus: recommended personal protective equipment for the orthopaedic and trauma surgeon. Knee Surgery, Sports Traumatology, Arthroscopy 28:1690-1698.

Kemkes RI, 2020. Begini aturan pemakaian masker kain yang benar. https://www.kemkes.go.id/pdf.php?id=2 0060900002.

Lestari PA, Hanindharputri MA, Lestari Ni PEB, 2020. Gerakan 1.000 masker untuk pencegahan virus Covid-19 di pasar Yadnya Desa Adat Kesiman Denpasar Timur. Jurnal Lentera Widya, 1 (2): 39 - 44 (online). https://jurnal.stdbali.ac.id/index.php/lenterawidya/article/vie w/105.

Mahmood A, Eqan M, Pervez S, Tabinda AB, Yasar A, Brindhadevi K, Pugazhendhi A, 2020. COVID-19 and frequent use of hand sanitizers; human health and environmental hazards by exposure pathways.Sci Total Environ. 10; 742: 140561.

Muscogiuri G, Barrea L, Savastona S, Colao A, 2020. Nutritional recommendation for COVID-19 quarantine. European Journal of
Clinical Nutrition.https://doi.org/10.1038/ s41430-020-0635-2.

Sari DP \& Atiqoh NS, 2020.Hubungan antara pengetahuan masyarakat dengan kepatuhan penggunaan masker sebagai upaya pencegahan penyakit COVID-19 di Ngronggah. INFOKES, VOL 10, hal.52-55.

Samarghandian S, Farkhondeh T, \& Samini F, 2017. Honey and health: A review of recent clinical

research. Pharmacognosyresearch, 9(2), 121-127. https://doi.org/10.4103/09748490.204647.

Setiati S dan Azwar MK, 2020. COVID-19 and Indonesia. Acta Med Indones, Vol. 52, No. 1 hal. 84-89.

UlyYA, 2020. Selain jamu, madu dan susujuga tingkatkan imun tubuh. Editor : SA Nursastrihttps://www.kompas.com/ sains/read/2020/06/11/170300423/selainjamu-madu-dan-susu-juga-tingkatkanimun-tubuh.

WHO, 2020. Anjuran mengenai penggunaan masker dalam konteks COVID19panduan sementara .6 April 2020.

Yuliarti N, 2015. Khasiat madu untuk kesehatan dan kecantikan. Yogyakarta: Rapha publishing. 